Article

\title{
Diagnosing Phosphorus Limitation in Subtropical Forests in China under Climate Warming
}

\author{
Na Wang 1,2®, Mei Huang 1,* Fengxue Gu ${ }^{3}$, Huimin Yan ${ }^{4}$, Shaoqiang Wang ${ }^{1,5}$, Honglin He ${ }^{1}$, \\ Zhaosheng Wang ${ }^{1}{ }^{\mathbb{D}}$, Xiangyang Sun ${ }^{6}$, Wenting $\mathrm{Xu}^{7}$, Fengting Yang ${ }^{1}$ and Guowei $\mathrm{Chu}{ }^{8}$ \\ 1 Key Laboratory of Ecosystem Network Observation and Modeling, Institute of Geographic Sciences and \\ Natural Resources Research, Chinese Academy of Sciences, Beijing 100101, China; \\ wangn.16s@igsnrr.ac.cn (N.W.); sqwang@igsnrr.ac.cn (S.W.); hehl@igsnrr.ac.cn (H.H.); \\ wangzs@igsnrr.ac.cn (Z.W.); yangft@igsnrr.ac.cn (F.Y.) \\ 2 University of Chinese Academy of Sciences, Beijing 100049, China \\ 3 Key Laboratory of Dryland Agriculture, Ministry of Agriculture, Institute of Environment and Sustainable \\ Development in Agriculture, Chinese Academy of Agricultural Sciences, Beijing 100081, China; \\ xuefgu@163.com \\ 4 Institute of Geographic Sciences and Natural Resources Research, Chinese Academy of Sciences, \\ Beijing 100101, China; yanhm@igsnrr.ac.cn \\ 5 College of Resources and Environment, University of Chinese Academy of Sciences, Beijing 100049, China \\ 6 Key Laboratory of Mountain Surface Processes and Ecological Regulation, Institute of Mountain Hazards \\ and Environment, Chinese Academy of Sciences, Chengdu 610000, China; sunxiangyang@imde.ac.cn \\ 7 State Key Laboratory of Vegetation and Environment Change, Institute of Botany, Chinese Academy of \\ Sciences, Beijing 100093, China; xuwt@ibcas.ac.cn \\ 8 Guangdong Provincial Key Laboratory of Applied Botany, South China Botanical Garden, Chinese Academy \\ of Sciences, Guangzhou 510650, China; cgw@scib.ac.cn \\ * Correspondence: huangm@igsnrr.ac.cn
}

Received: 13 February 2019; Accepted: 9 April 2019; Published: 12 April 2019 updates

\begin{abstract}
Phosphorus (P) is a fundamental component of plant organisms. Most of the Earth System Models (ESMs) project increases in future Net Primary Productivity (NPP) due to climate warming. However, large uncertainty exists in projected NPP due to future P limitation. Subtropical China is a region with high vegetation NPP, but its forests are mostly P limited. In this study, we used the simulations of Atmospheric-Vegetation Interaction Model 2 (AVIM2) to diagnose the P limitation in forests in this region, and found that climate warming in the period of 1951-2010 had enhanced P limitation. The P demand during 1981-2010 for Evergreen Broad-leaved Forest (EBF) and Evergreen Needle-leaved Forest (ENF) are 1.67 and 1.8 times than that during 1951-1980, respectively. The observed current Available Soil P (ASP) density in 4 representative forest sites in subtropical China varied between $940 \mathrm{mg} \cdot \mathrm{m}^{-2}$ and $2365 \mathrm{mg} \cdot \mathrm{m}^{-2}$, and the P demands account for $0.86 \%$ to $25.5 \%$ of the ASP for the period of 1951-2010. Future P demands are estimated to account for $3.2 \%$ to $68.3 \%$ of the current ASP at the end of this century for RCP8.5. Therefore, forests, especially plantations, in subtropical China are facing high risks of $\mathrm{P}$ limitation.
\end{abstract}

Keywords: climate warming; net primary productivity; phosphorus limitation; subtropical forest; China

\section{Introduction}

Phosphorus $(\mathrm{P})$ is a key component of biomacromolecules in all organisms, and it plays a crucial role in terrestrial ecosystems processes [1]. Theoretical and experimental studies have demonstrated that the terrestrial carbon (C) cycle is strongly affected by P availability [2,3], and the stoichiometry of 
$\mathrm{C}$, nitrogen $(\mathrm{N})$ and $\mathrm{P}$ in plant and soil affects assimilation and allocation of $\mathrm{C}$ in plant and ultimately affects the functioning of terrestrial ecosystems and the absorption of $\mathrm{CO}_{2}[4,5]$. P is derived primarily from rock weathering, and it is not clear if there is additional external $\mathrm{P}$ entering the ecosystem due to climate warming. However, the increase of $C$ in ecosystem due to climate warming is certain, which implies that the ecosystem will consume more $\mathrm{P}$ to maintain the consistent $\mathrm{C}: \mathrm{P}$ ratio. Therefore, climate warming may result in the $P$ limitation in ecosystem which will finally influence its $C$ uptakes.

Climate warming has profoundly affected the terrestrial ecosystem and global biogeochemical cycle, as the average global surface temperature has increased almost $1^{\circ} \mathrm{C}$ since preindustrial times [6]. Previous studies have shown that climate warming enhances photosynthesis, and thus promotes vegetation growth $[7,8]$. Net primary productivity (NPP) is the difference of gross photosynthesis minus autotrophic respiration, which represents the function of ecosystem and is considered as a critical indicator for vegetation growth. Large-scale model simulations have shown that both global [9-11] and China mean NPP have increased significantly in recent decades [12-16]. The increase of NPP implies that vegetation takes up and stores more $C$ in the ecosystem, which indicates more $P$ consumption in the ecosystem. However, ecosystems begin their existence with a fixed complement of $\mathrm{P}$ from which even very small losses cannot readily be replenished [17].

Globally, N and P are the most common nutrients limiting plant growth and soil C storage [18]. Previous studies show that some tropical forests and savanna ecosystems are P limited because of their old soil age $[19,20]$. Mahowald et al. (2008) predicted that as humans continue to preferentially increase $\mathrm{N}$ deposition, ecosystems may shift from $\mathrm{N}$ limitation to $\mathrm{P}$ limitation [21]. Subtropical China is the region with the highest vegetation gross primary productivity (GPP), and its regional total GPP contributes the largest proportions in China's total GPP [22]. Previous experiments have shown that some of the subtropical forests in China are P limited, and some are both P and N limited [23-27]. With the intensification of climate warming, it is expected that $\mathrm{P}$ will be a crucial nutrient factor affecting the $C$ uptake and storage in subtropical China. However, the spatial and temporal distribution of current $\mathrm{P}$ consumptions and future $\mathrm{P}$ limitation in subtropical China are still unclear. Therefore, it is of great importance to explore the dynamic changes of $P$ demand in subtropical China, which will be of great help for understanding the potential threats of $\mathrm{P}$ deficit in subtropical China and to make effective strategy to cope with climate change.

Modeling and diagnosing are two major approaches to studying the P limitation in ecosystems. In terms of the modelling approach, some process-based models have been developed in the last 20 years for explicitly modeling P cycle. For example, Wang et al. (2010) developed a P model to simulate the global distribution of P limitation on NPP at steady state, and they found that tropical vegetation NPP was reduced by about $20 \%$ on average by P limitation [28]. Goll et al. (2012) incorporated a P cycle into a land surface model and found that the average plant uptake of P over 1970-1999 in tropical and temperate forests was in the range of $0.18-0.71 \mathrm{~g} \cdot \mathrm{m}^{-2} \cdot \mathrm{a}^{-1}$ [29]. Yang et al. (2014) introduced P dynamics and C-N-P interactions into the community land model version 4 with a prognostic $\mathrm{C}$ and $\mathrm{N}$ model (CLM4-CN) to simulate the effects of elevated $\mathrm{CO}_{2}$ concentration on plant $\mathrm{P}$ availability and got meaningful results, and they found that tropical forest response to elevated $\mathrm{CO}_{2}$ can only be predicted if the interactions between $\mathrm{C}$ cycle and nutrient dynamics are well understood and represented in models [30]. Therefore, more scientific experiments are needed for understanding the C-P interactions, and the modeling approach for understanding $\mathrm{P}$ limitation still remains highly uncertain.

In terms of the diagnostic approach, Peñuelas et al. (2013) used globally uniform stoichiometric ratios for vegetation and soil and calculated $\mathrm{N}$ and $\mathrm{P}$ demands for given changes in $\mathrm{C}$ pools during 2000-2099, and found that global P demand are ranged between -0.9 and $4.3 \mathrm{Pg} P$ for the lower projection for Representative Concentration Pathway (RCP) 2.6 and between -1.7 and $6.5 \mathrm{Pg} P$ for RCP8.5, with negative values indicating a P surplus [31]. However, the size of the global plant-accessible labile P soil pool is only $13.2 \mathrm{Pg} \mathrm{P}$, and, hence, the limited $\mathrm{P}$ availability is likely to reduce future carbon storage by natural ecosystems during this century. Wieder, et al. (2015) used the NPP outputs from the Coupled Climate Carbon Cycle Model Intercomparing Projects (CMIP5) models over 1860-2100 and 
estimated annual new $\mathrm{N}$ and $\mathrm{P}$ inputs to evaluate how $\mathrm{CO}_{2}$ fertilization effects could be constrained by nutrient availability [32]. They found that accounting for $\mathrm{N}$ and $\mathrm{P}$ limitation would lower projected end-of-century estimates of NPP by 19\%. The approaches of Peñuelas et al. (2013) [31] and Wieder et al. (2015) [32] were based on C stock and NPP changes, respectively. Sun et al. (2017) used both C stock and NPP-based approaches in a consistent framework to investigate whether available soil $\mathrm{P}$ (ASP) can support the P demand with four scenarios of soil P availability, and they found that there are large differences between the NPP-based demand and C stock-based demand, and the diagnostic approach still remains uncertain [33].

Previous diagnostic approaches showed contradictory results in prediction of $\mathrm{P}$ limitation in subtropical China. For example, Sun et al. (2017) [33] estimated the values of additional P demand under RCP8.5 in subtropical China were negative based on C stock method, but positive based on NPP method. Therefore, the estimation of $\mathrm{P}$ limitation in subtropical China still remains highly uncertain.

The uncertainty in estimates of $\mathrm{P}$ limitation mainly comes from three sources: The uncertainty of the C:P ratios for plant organs, the NPP allocation to leaves, roots and wood and the estimates of the ASP. To refine the $\mathrm{P}$ limitation study in subtropical China, we obtained biome-specific C:P ratios for plant organs, and the values of NPP allocation to leaves, roots and wood from literatures which reported field measurements in subtropical China. Furthermore, we conducted field investigations in four representative forest ecosystems to obtain the current ASP density. The main objectives of this study are: (1) To diagnose the past $P$ consumption in subtropical forests in China based on field observations; (2) to investigate future P demand under climate warming; and (3) to understand factors controlling the spatial distribution of $\mathrm{P}$ demand in subtropical China. The ultimate objective is to find the potential risk of $\mathrm{P}$ deficit in subtropical China and to provide scientific suggestions for forest managers to cope with climate change. To achieve these objectives, we used NPP outputs from an atmosphere-vegetation interaction model (AVIM2) in combination with observed stoichiometric relationships to diagnose the past $\mathrm{P}$ demand and with the field-observed ASP to diagnose the P limitation under RCP8.5. This approach can improve our understanding of the P limitation in China's subtropical forest, and the results may provide useful information for forest managers to cope with climate change.

\section{Materials and Methods}

\subsection{Study Area}

The subtropical region in mainland China, which consists of 16 provincial administrative regions, with a total area of 2.26 million square kilometers, was taken as the study area (Figure 1). The climate in the study area is warm and humid and suitable for vegetation growth. Forests dominate $42 \%$ of the study area, including $13.29 \%$ evergreen broad-leaved forest (EBF), $27.39 \%$ evergreen needle-leaved forest (ENF) and $1.38 \%$ deciduous broad-leaved forest (DBF).

\subsection{Data Sources}

The meteorological data for driving the AVMI2 model is from the Global Meteorological Forcing Dataset (GMFD) of Princeton University, with a spatial resolution of $1^{\circ} \times 1^{\circ}$ and a time interval of $3 \mathrm{~h}$ [34]. The vegetation map used in this model is the global land cover dataset (GLC2000), which is available at http://www-gem.jrc.it/glc2000/objectivesGLC2000.htm, and the soil texture data is a combination of three regional maps of similar scales $(1: 14,000,000,1: 4,000,000$ and 1:5,000,000) [35]. All of the model driven datasets are interpolated to the spatial resolution of $0.1^{\circ} \times 0.1^{\circ}$. The future temperature and NPP data are the simulations of BCC-CSM 1.1, which was obtained from CMIP5 multi-model dataset through the Program for Climate Model Diagnosis and Intercomparison (PCMDI) at http://pcmdi9.1lnl.gov/esgf-web-fe/. 


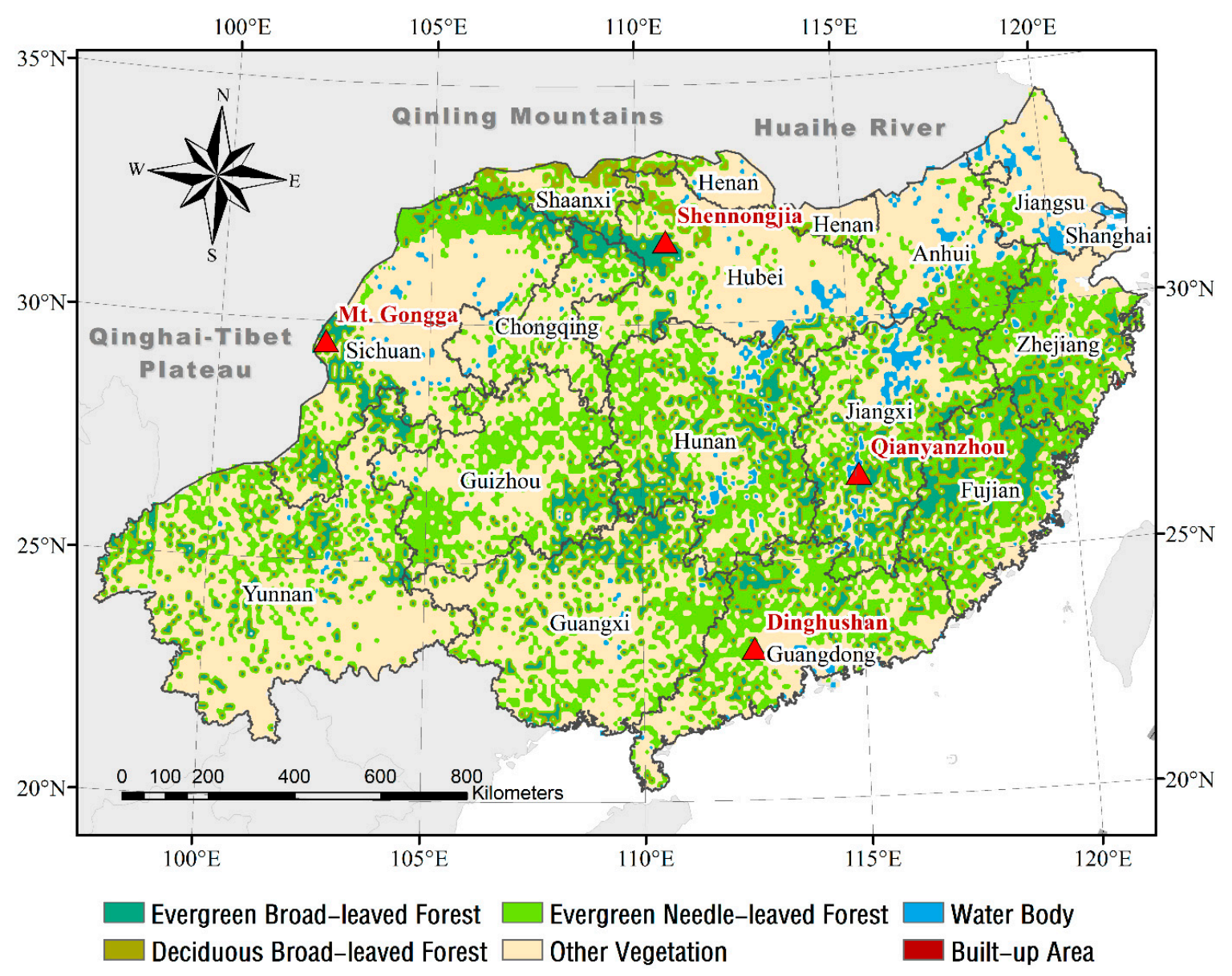

Figure 1. Spatial distribution of forest type in the study area and the location of field sampling sites.

\subsection{Methods}

\subsubsection{Atmosphere-Vegetation Interaction Model (AVIM2)}

The AVIM2 used in this study is a process-based model which was first developed by Ji (1995) [36], and it is the land surface component of the BCC-CSM 1.1. BCC-CSM 1.1 is one to the ESMs, which participate in CMIP5. AVIM2 consists of three modules: Plant-growth module, soil-vegetation-atmosphere transfer module and soil $\mathrm{C}$ and $\mathrm{N}$ dynamics module. The detailed description of the modules in AVIM2 can be found in Ji (1995) [36] and Huang et al. (2007) [37]. The AVIM2 simulations are widely used in studying the responses of terrestrial ecosystem C cycle to climate change in China [16,38]. In AVIM2, GPP is the aggregate amount of leaf photosynthesis at every model time step, and NPP is the difference between GPP and a similarly aggregated amount of autotrophic respiration ( $\mathrm{Ra}$, as the sum of maintenance and growth respiration).

\subsubsection{Diagnose of Additional P Demand}

The method used to diagnose the additional $\mathrm{P}$ demand in forest ecosystems based on NPP changes is mainly in reference to that of Sun et al. (2017) [33]. Here, additional means the demand due to the increases of C storage since 1950. We assume that $100 \%$ of the plant uptake of P by NPP is equal to the P supply from all sources at 1950; that is, the additional $\mathrm{P}$ demand was zero at 1950 . Then, the additional $\mathrm{P}$ demand $\left(\Delta \mathrm{P}_{i,(t)}\right)$ in ecosystems related to NPP change is calculated as the total $\mathrm{P}$ demand minus changes in recycled $\mathrm{P}$ supply from leaf $\mathrm{P}$ resorption $\left(\Delta P_{R S B, i(t)}\right)$ and changes in the NPP uptake of mineralized $\mathrm{P}\left(\Delta P_{M R, i(t)}\right)$ : 


$$
\Delta \mathrm{P}_{i,(t)}=\sum_{j=1}^{3} \frac{\Delta N P P_{i, j,(t)} \times d_{i, j}}{r_{i, j}}-\Delta P_{R S B, i(t)}-\Delta P_{M R, i(t)}
$$

where $i$ and $t$ represent forest type and year, respectively, and the numbers 1,2 and 3 indexed by $j$ represent the $\mathrm{C}$ pool for root, wood and leaf, respectively. The $r_{i, j}$ is the C:P ratios in the corresponding $\mathrm{C}$ pool, and $d_{i, j}$ is the fraction of NPP allocated to the C pool of leaf, wood and root, respectively.

$\triangle N P P_{i, j,(t)}$ is the difference of NPP between two years:

$$
\triangle N P P_{i, j,(t)}=N P P_{i, j,(t)}-N P P_{i, j,(t-1)}
$$

The changes of leaf P resorption available for the increment of NPP of the next year was assumed to be only associated with the leaf NPP change, which is given by:

$$
\Delta P_{R S B, i,(t)}=\frac{\sum_{j=1}^{3} \Delta N P P_{i, j,(t)} \times d_{i, 3} \times R S B_{i}}{r_{i, 3}}
$$

where $R S B_{i}$ is the adsorption coefficient.

The mineralization of P from SOM and litter is another source of inorganic P for NPP uptake, which is the difference between microbial immobilization and gross soil organic matter and litter mineralization. This flux $\left(\Delta P_{M R, i(t)}\right)$ was inferred using two idealized scenarios. Scenario $1\left(\mathrm{~S}_{1}\right)$ assumes low mineralization, that is, only P in fallen leaves can be mineralized and support NPP in the following year, while P in wood and root components of litter is unavailable for vegetation to recycle. This is given by:

$$
\Delta P_{M R, i, S_{1}(t)}=\frac{\Delta N P P_{i,(t)} \times d_{i, 3} \times\left(1-R S B_{i}\right)}{r_{i, 3}}
$$

Scenario $2\left(\mathrm{~S}_{2}\right)$ assumes high mineralization, that is, $90 \%$ of $\mathrm{P}$ in the wood and root litter is recycled in addition to all $\mathrm{P}$ in fallen leaves each year. This is given by:

$$
\Delta P_{M R, i, S_{2} t}=\frac{\Delta N P P_{i,(t)} \times d_{i, 3} \times\left(1-R S B_{i}\right)}{r_{i, 3}}+f r a c \times \Delta N P P_{i,(t)} \times\left(\frac{d_{i, 2}}{r_{i, 2}}+\frac{d_{i, 1}}{r_{i, 1}}\right)
$$

where frac is the fraction of $\mathrm{P}$ in litter reused in the ecosystems, which is set as 0.9.

The accumulated additional $\mathrm{P}$ demand (AAPD) for a given period is given by:

$$
A A P D=\sum_{t 1}^{t 2} \Delta \mathrm{P}_{i,(t)}
$$

where $t_{1}$ and $t_{2}$ represent the start and end year, respectively.

The parameters used for diagnosing P limitation are listed in Table 1 , in which $r_{i, j}$ is obtained from literatures that reported the field measurements in subtropical forests in China. We used the fractions of $C$ pools (leaves, wood and roots) to total vegetation C to represent NPP allocated to leaves, wood and roots, and $d_{i, j}$ were obtained by averaging over 200 field observations in subtropical forests [22]. 
Table 1. Parameters and sources for diagnosing phosphorus limitation in subtropical forests in China.

\begin{tabular}{|c|c|c|c|c|c|c|c|}
\hline & & $r_{i, j}$ & Ref & $d_{i, j}$ & Ref & RSB & Ref \\
\hline \multirow{3}{*}{ EBF } & root & $\begin{array}{c}433.62 \\
(177.02-585.82)\end{array}$ & {$[39,40]$} & 0.22 & \multirow{9}{*}{ [22] } & \multirow{3}{*}{0.58} & \multirow{9}{*}{ [41] } \\
\hline & wood & $\begin{array}{c}479.62 \\
(269.02-828.16)\end{array}$ & {$[39,40]$} & 0.72 & & & \\
\hline & leaf & $\begin{array}{c}431.41 \\
(208.11-779.13)\end{array}$ & {$[39,42-46]$} & 0.06 & & & \\
\hline \multirow{3}{*}{ ENF } & root & $\begin{array}{c}386.92 \\
(224.84-404.80)\end{array}$ & {$[39,40]$} & 0.19 & & \multirow{3}{*}{0.58} & \\
\hline & wood & $\begin{array}{c}726.67 \\
(554.01-1025.48)\end{array}$ & {$[39,40]$} & 0.73 & & & \\
\hline & leaf & $\begin{array}{c}568.55 \\
(333.12-843.06)\end{array}$ & {$[39,42-46]$} & 0.08 & & & \\
\hline \multirow{3}{*}{ DBF } & root & $513(410-615)$ & {$[39,40]$} & 0.24 & & \multirow{3}{*}{0.46} & \\
\hline & wood & $2187(1750-2625)$ & [39] & 0.70 & & & \\
\hline & leaf & 622 (192-1052) & {$[39,42-46]$} & 0.06 & & & \\
\hline
\end{tabular}

EBF, ENF and DBF are the abbreviations for evergreen broad-leaved forest, evergreen needle-leaved forest and deciduous broad-leaved forest, respectively.

\subsubsection{Theil-Sen Regression}

The Theil-Sen regression analysis is used to study the trends of NPP and P demand in this study. Theil-Sen regression is a method for robust linear regression that chooses the median slope among all lines through pairs of two-dimensional sample points. It has been called the most popular nonparametric technique for estimating a linear trend and is widely used in geoscience and remote sensing studies $[47,48]$.

For a set of two-dimensional points $\left(x_{i}, y_{i}\right)$, the slope $\left(\operatorname{Sen}_{i, j}\right)$ is estimated as follows:

$$
\operatorname{Sen}_{i, j}=\operatorname{Median}\left[\frac{y_{i}-y_{j}}{x_{i}-x_{j}}: x_{i} \neq x_{j}, i<j=1,2, \ldots, n\right]
$$

The Mann-Kendall trend test is used to test the significance of the trends $[49,50]$.

\subsubsection{Field Sampling}

The field investigations were conducted in July 2018 in Shennongjia, Qian Yanzhou, Mt. Gongga and Dinghushang. The locations of the forest sites, including Shennongjia $\left(109^{\circ} 59^{\prime}-110^{\circ} 58^{\prime} \mathrm{E}\right.$, $\left.31^{\circ} 15^{\prime}-31^{\circ} 57^{\prime} \mathrm{N}\right)$, Mt. Gongga $\left(29^{\circ} 20^{\prime}-30^{\circ} 20^{\prime} \mathrm{N}, 101^{\circ} 30^{\prime}-102^{\circ} 15^{\prime} \mathrm{E}\right)$, Dinghushang $\left(23^{\circ} 09^{\prime}-23^{\circ} 11^{\prime} \mathrm{N}\right.$, $112^{\circ} 31^{\prime}-112^{\circ} 34^{\prime}$ E) and Qian Yanzhou $\left(26^{\circ} 12^{\prime}-26^{\circ} 34^{\prime} \mathrm{N}, 115^{\circ} 10^{\prime}-115^{\circ} 23^{\prime} \mathrm{E}\right)$, are shown in Figure 1.

Shennongjia is located in the broad-leaved forest ecological zone of Qinba Mountain, which is a key area for biodiversity conservation in China. The forest in Shennongjia represents a natural mountainous forest in the northern subtropical China. The annual mean temperature is $10.6{ }^{\circ} \mathrm{C}$, and the annual total precipitation is $1219 \mathrm{~mm}$ in Shennongjia [51]. The soil samples were obtained at the altitudes of $760 \mathrm{~m}$ for EBF and $2080 \mathrm{~m}$ for ENF. The soils of both EBF and ENF are yellow-brown clay.

Mt. Gongga is located in the transitional area between China's eastern monsoon subtropics and the frigid area of the Tibetan Plateau. The forest in Mt. Gongga represents a natural mountainous forest in western subtropical China. The annual mean temperature is $4.4{ }^{\circ} \mathrm{C}$ and the annual total precipitation is $1910 \mathrm{~mm}$ in Mt. Gongga. The soil samples were obtained at the altitudes of $2265 \mathrm{~m}$ for EBF and $3082 \mathrm{~m}$ for ENF. The soil for EBF is brown silt soil and that for ENF is dark-brown silt soil.

Dinghushan is located in southern tropical China, and its forest represents a southern tropical natural forest in China. The annual total precipitation is $1680 \mathrm{~mm}$ and the annual mean temperature is $22.3{ }^{\circ} \mathrm{C}$ in Dinghushan [52]. The sampling plots were located at the altitudes of $89 \mathrm{~m}$ for EBF and $210 \mathrm{~m}$ for ENF. The soils for both EBF and ENF are red loam. 
Qian Yanzhou is located at the central subtropical region in China, with an annual total precipitation of $1485 \mathrm{~mm}$ and an annual mean temperature of $17.9^{\circ} \mathrm{C}$. The plantation in Qian Yanzhou represents a man-made forest in the central subtropical region. The soil samples were obtained at the altitudes of $55 \mathrm{~m}$ for EBF and $103 \mathrm{~m}$ for ENF. The soils are red sandy loam soils for both EBF and ENF.

Four soil quadrats $(10 \times 10 \mathrm{~m}$ each) were set under each EBF and ENF in each forest site. Five soil samples were randomly taken at the top $50 \mathrm{~cm}$ of soils in each quadrat, and they were evenly mixed together. For each forest type in each site, four soil samples were taken back for analysis, and all soil samples were air-dried and had small stones and any visible plant and root residues removed, and were then ground and passed through a $2 \mathrm{~mm}$ sieve for analysis.

\subsubsection{Laboratory Analysis}

The ASP is the main source of $\mathrm{P}$ that plants can absorb and utilize, which represents the actual $\mathrm{P}$ supply capacity in soil. Different approaches for calculating ASP have resulted in a large discrepancy in the estimates, which is the major source of uncertainty in P limitation study [28-30,33]. To reduce this uncertainty, we conducted field observations in representative forest sites in the subtropical region to estimate ASP. ASP is considered as the sum of resin-extractable $\mathrm{P}$, bicarbonate-extractable inorganic $\mathrm{P}$ and organic P. As our soil samples were obtained from the moderate weathering rocks, and the soil $\mathrm{pH}$ values of the soil samples are between 3.5 and 5.2, the Bray-I method was used for analysis of ASP [53].

\section{Results}

\subsection{Spatial Pattern of NPP and NPP Trends}

Figure 2a shows the spatial distribution of forest NPP averaged over 1950 to 2010 in the study area. The average NPP varies between $400 \mathrm{gC} \cdot \mathrm{m}^{-2} \cdot \mathrm{a}^{-1}$ and $900 \mathrm{gC} \cdot \mathrm{m}^{-2} \cdot \mathrm{a}^{-1}$, and the higher NPP values are mainly distributed in the southeastern and western forest areas, including forests in the Fujian, Jiangsu, Sichuan and Yunnan provinces. All forest NPP show positive trends during 1950-2010 (Figure 2b), and the Mann-Kendall test confirms that the increasing trends are all significant at 95\% confidence level. The trends in NPP are in the range of $1-3 \mathrm{gC} \cdot \mathrm{m}^{-2} \cdot \mathrm{a}^{-2}$ in the study area, with the higher values (greater than $2 \mathrm{gC} \cdot \mathrm{m}^{-2} \cdot \mathrm{a}^{-2}$ ) in central subtropical China, including southwestern Sichuan, Guizhou, Yunnan and most of the Jiangxi province.
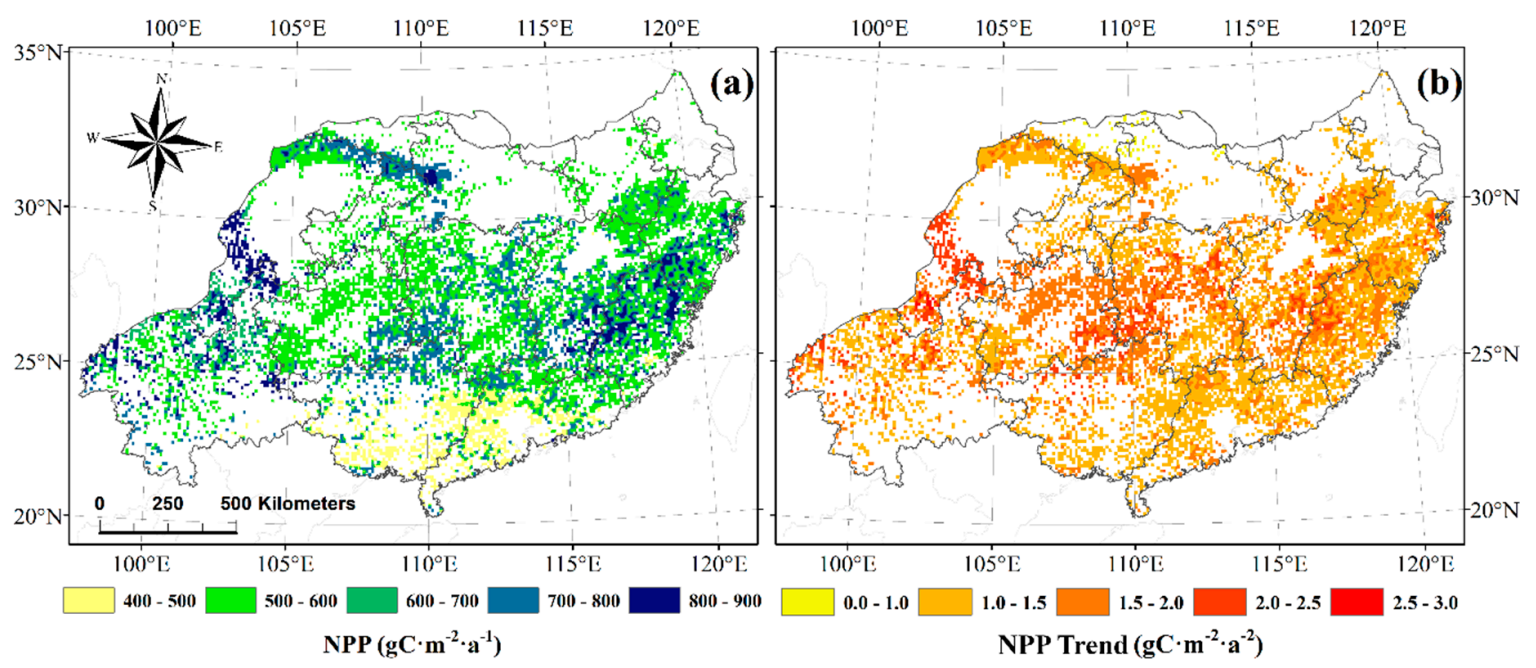

Figure 2. Net primary productivity (NPP) in study area. (a) Spatial distribution of forest NPP averaged over 1950-2010 and (b) forest NPP trends for 1950-2010. 


\subsection{Changes of NPP for Different Forest Types}

The changes of NPP time series for EBF, ENF and DBF are compared in Figure 3. The mean NPP averaged over 1950-2010 for EBF is $805 \mathrm{gC} \cdot \mathrm{m}^{-2} \cdot \mathrm{a}^{-1}$, which is the highest among the three forest types, followed by $573 \mathrm{gC} \cdot \mathrm{m}^{-2} \cdot \mathrm{a}^{-1}$ for DBF and $452 \mathrm{gC} \cdot \mathrm{m}^{-2} \cdot \mathrm{a}^{-1}$ for ENF. The slope of EBF is $1.93 \mathrm{gC} \cdot \mathrm{m}^{-2} \cdot \mathrm{a}^{-2}$, which is the highest among those of the three forest types, while the slopes of ENF and DBF are $1.33 \mathrm{gC} \cdot \mathrm{m}^{-2} \cdot \mathrm{a}^{-2}$ and $1.12 \mathrm{gC} \cdot \mathrm{m}^{-2} \cdot \mathrm{a}^{-2}$, respectively. The average NPP slope for the three forest types is $1.46 \mathrm{gC} \cdot \mathrm{m}^{-2} \cdot \mathrm{a}^{-2}$. Piao et al. (2011) reported the NPP slopes in Southern China were greater than $3 \mathrm{gC} \cdot \mathrm{m}^{-2} \cdot \mathrm{a}^{-1}$ during $1980-2002$ [54], and Gu et al. (2017) estimated an NPP slope of $2 \mathrm{gC} \cdot \mathrm{m}^{-2} \cdot \mathrm{a}^{-2}$ in southern China during 1960-2010 [15]. The study period for Gu et al. (2017) [15] is close to that of this study, and their estimates are close to our estimates for EBF, but slightly greater than our estimates for ENF and DBF.
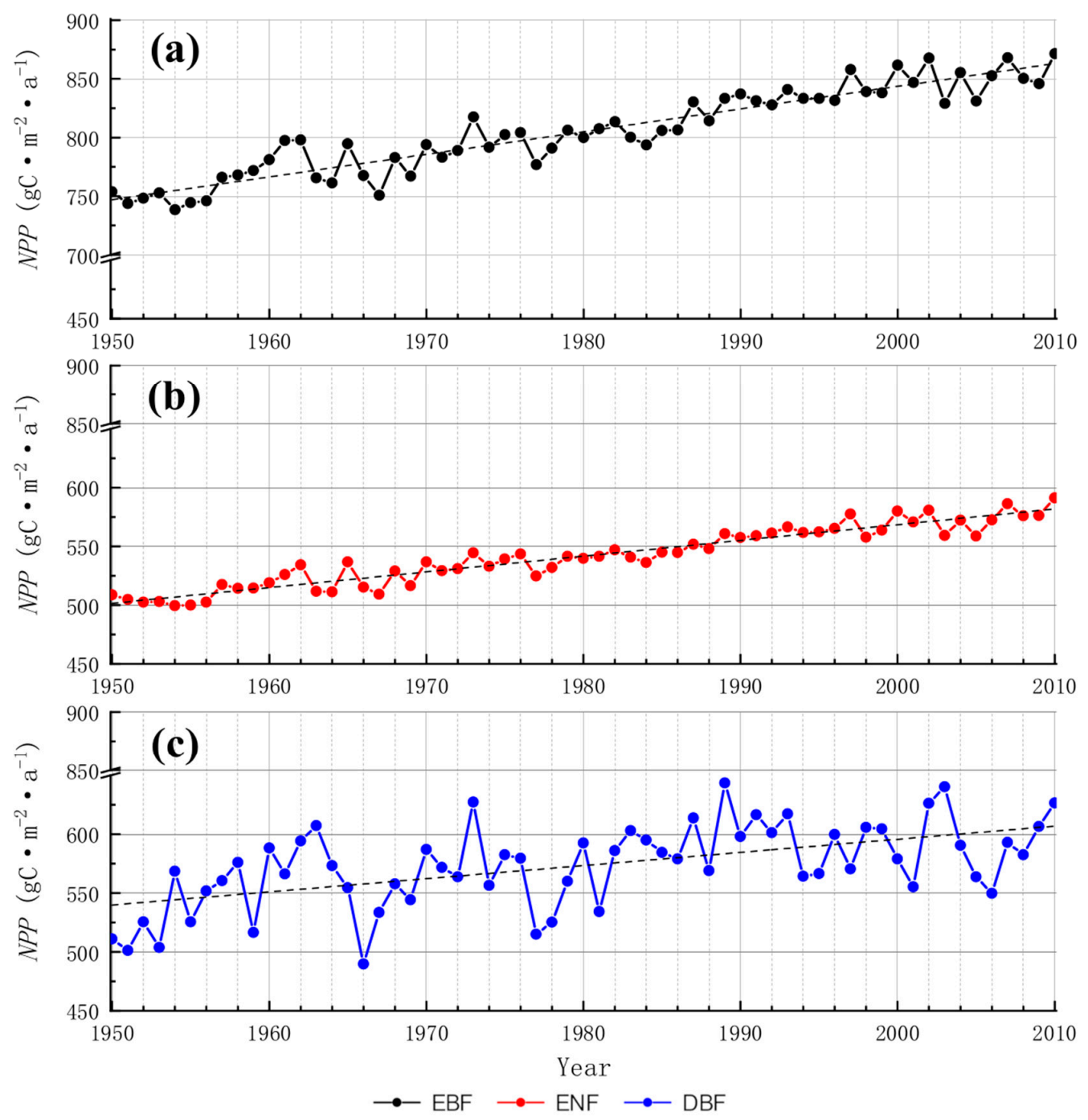

Figure 3. Forest NPP changes during 1950-2010, averaged over: (a) evergreen broad-leaved forest (EBF), (b) evergreen needle-leaved forest (ENF) and (c) deciduous broad-leaved forest (DBF).

\subsection{Spatial Pattern of Additional Accumulated Phosphorus Demand}

The spatial distribution of AAPD for the period of 1951-2010 for $\mathrm{S}_{1}$ is similar as that for $\mathrm{S}_{2}$, but differs from $S_{2}$ in values. The AAPD are between $0.064-0.3 \mathrm{gC} \cdot \mathrm{m}^{-2}$ for $\mathrm{S}_{1}$ and between $0.005-0.064 \mathrm{gC} \cdot \mathrm{m}^{-2}$ for $\mathrm{S}_{2}$ (Figure 4). The higher values mainly distributed in central subtropical China, including northeastern and southwestern Sichuan, and northwestern Yunnan, with values between 0.25 and $0.30 \mathrm{gC} \cdot \mathrm{m}^{-2}$ for $\mathrm{S}_{1}$ and 0.016 and $0.064 \mathrm{gC} \cdot \mathrm{m}^{-2}$ for $\mathrm{S}_{2}$. 


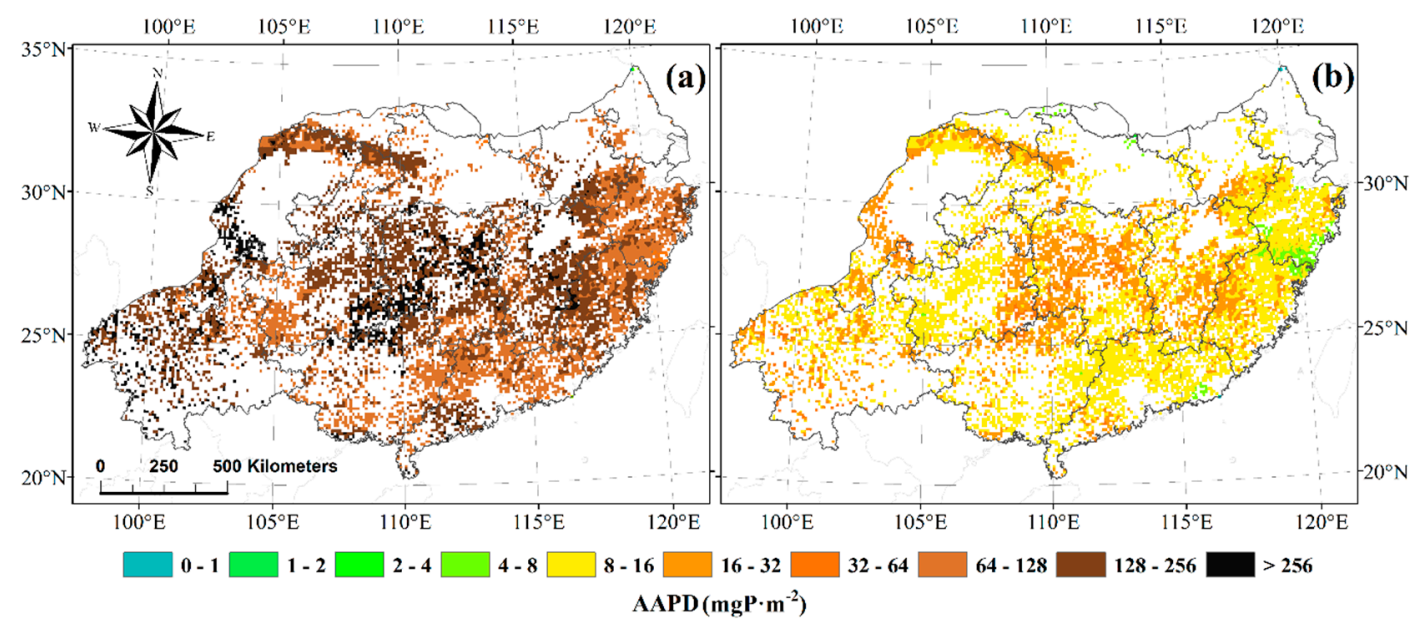

Figure 4. Spatial distribution of additional accumulated phosphorus demand (AAPD) for the period of 1951-2010 for: (a) $S_{1}$ and (b) $S_{2}$. $S_{1}$ and $S_{2}$ are the scenarios for the low and high mineralization rates, respectively.

Figure 5 compares the AAPD for the first (1951-1980) and the latter (1981-2010) 30 years for $S_{1}$ and $S_{2}$. For both $S_{1}$ and $S_{2}$, the AAPD in the latter 30 years was mostly higher than that in the first 30 years and the higher AAPD values (greater than $0.128 \mathrm{gC} \cdot \mathrm{m}^{-2}$ for $\mathrm{S}_{1}$ and greater than $0.016 \mathrm{gC} \cdot \mathrm{m}^{-2}$ for $S_{2}$ ) sporadically distributed in the western subtropical China in the first 30 years, but occupied large central and eastern subtropical regions in the latter 30 years.

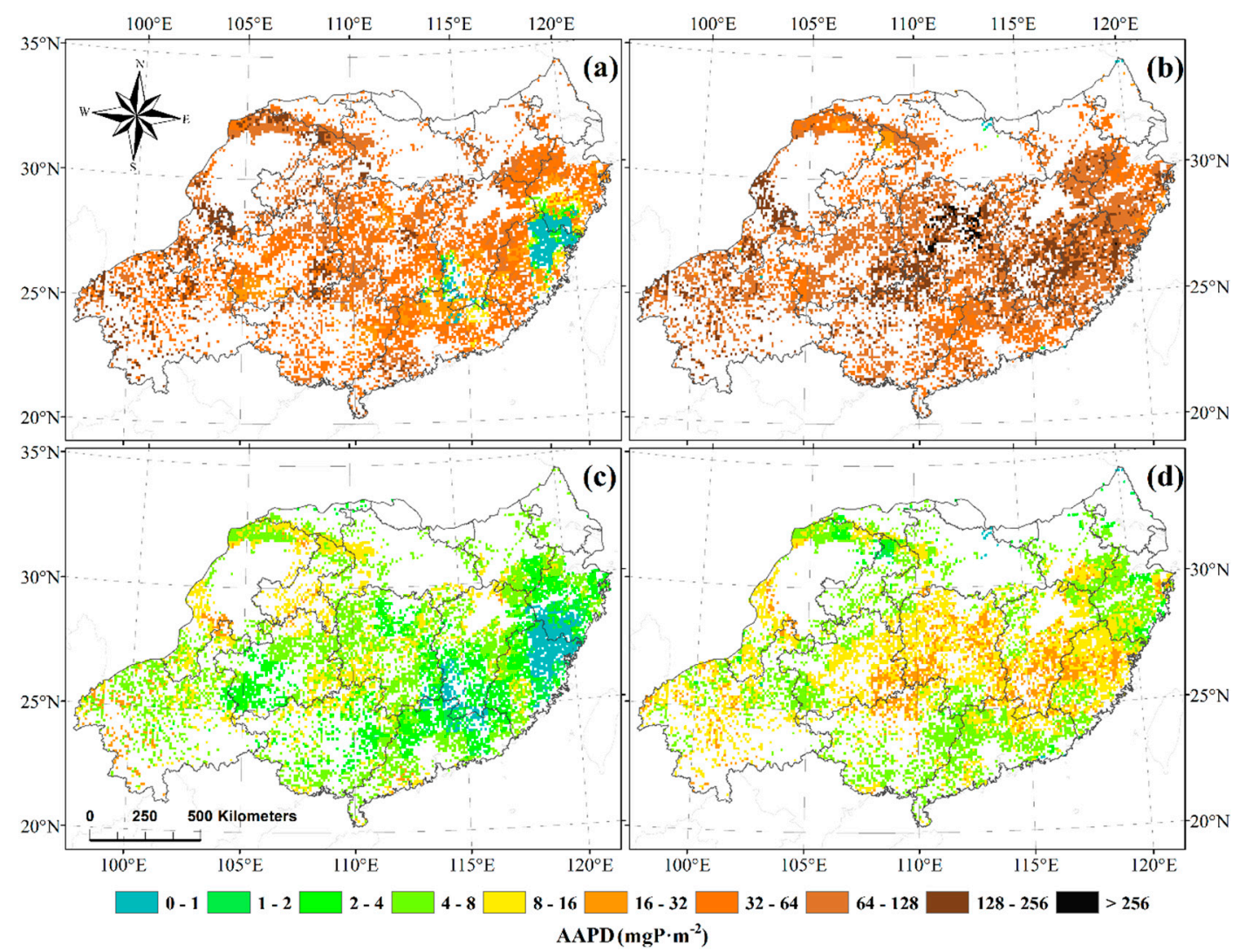

Figure 5. Additional accumulated phosphorus demand (AAPD) in the period of: (a) 1951-1980 for $\mathrm{S}_{1}$; (b) 1981-2010 for $\mathrm{S}_{1}$; (c) 1951-1980 for $\mathrm{S}_{2}$; and (d) 1981-2010 for $\mathrm{S}_{2} . \mathrm{S}_{1}$ and $\mathrm{S}_{2}$ are the scenarios for the low and high mineralization rates, respectively. 
We take $S_{1}$ as an example to illustrate the changes of the spatial pattern of AAPD. For the first 30 years, the AAPD was below $0.032 \mathrm{gC} \cdot \mathrm{m}^{-2}$ in $16 \%$ of the total forest area, and was in the range of $0.032-0.064 \mathrm{gC} \cdot \mathrm{m}^{-2}$ and $0.064-0.256 \mathrm{gC} \cdot \mathrm{m}^{-2}$ in $47 \%$ and $37 \%$ of the total forest area, respectively. However, for the latter 30 years, only $1 \%$ of the total forest area was covered by AAPD below $0.032 \mathrm{gC} \cdot \mathrm{m}^{-2}$, while $18 \%$ and $80 \%$ of the total forest areas were covered by AAPD in the range of $0.032-0.064 \mathrm{gC} \cdot \mathrm{m}^{-2}$ and $0.064-0.256 \mathrm{gC} \cdot \mathrm{m}^{-2}$, respectively.

\subsection{Changes of Additional Phosphorus Demand for Different Forest Types}

The additional P demand averaged over forest types increased greatly during 1951-2010 (Figure 6). Linear regression analyses show that the slopes of additional $\mathrm{P}$ demand for EBF, ENF and DBF are 3.52, 1.85 and $0.81 \mathrm{mg} \cdot \mathrm{m}^{-2} \cdot \mathrm{a}^{-1}$ for $\mathrm{S}_{1}$, and are $0.35,0.18$ and $0.08 \mathrm{mg} \cdot \mathrm{m}^{-2} \cdot \mathrm{a}^{-1}$ for $\mathrm{S}_{2}$, respectively. The positive trends in the additional P demand for EBF, ENF and DBF are all significant, at 99\% confidence level.

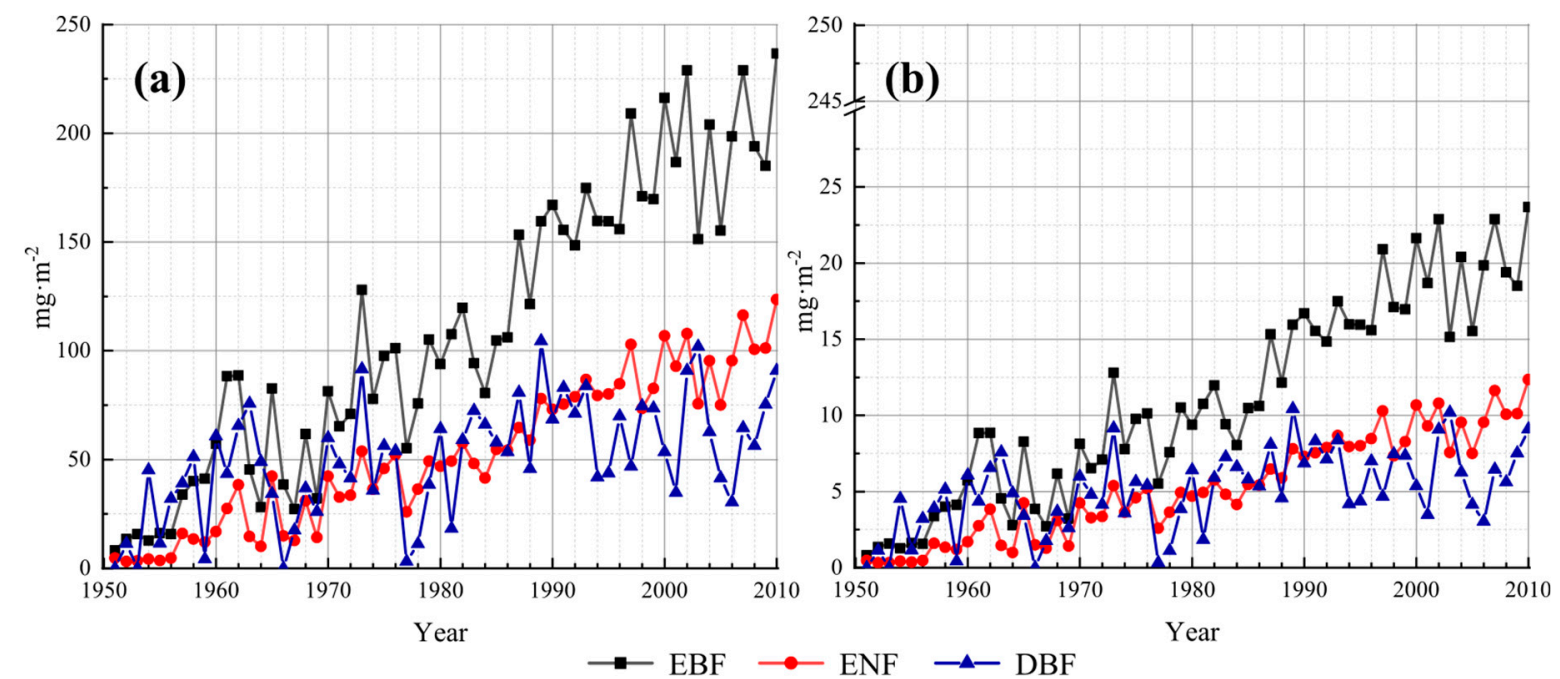

Figure 6. Changes of additional phosphorus demand averaged over EBF, DBF and ENF for: (a) $S_{1}$ and (b) $S_{2}$. EBF, DBF and ENF are the abbreviations for evergreen broad leaf forest, deciduous broad leaf forest and evergreen needle leaf forest, respectively. $S_{1}$ and $S_{2}$ are the scenarios for the low and high mineralization rates, respectively.

The AAPD values in the period of 1981-2010 are much greater than those in 1951-1980 for both EBF and ENF. Take $S_{1}$ for EBF as an example; the AAPD values are $85.7 \mathrm{mg} \cdot \mathrm{m}^{-2}$ and $142.77 \mathrm{mg} \cdot \mathrm{m}^{-2}$ for 1951-1980 and 1981-2010, respectively, and the latter is 1.67 times more than the former. For ENF, the AAPD for 1981-2010 is 1.8 times more than that for 1951-1980. The exceptional case occurred in DBF. The AAPD for DBF is $64 \mathrm{mg} \cdot \mathrm{m}^{-2}$ during $1951-1980$ and is $26 \mathrm{mg} \cdot \mathrm{m}^{-2}$ during $1981-2010$, which is only 0.41 times the former, implying a decreased growth rate in the latter 30 years. However, DBF occupies very small areas (1.38\%) of subtropical China, and the decreased growth rate in AAPD is not common in this region.

\subsection{The Latitudinal Distribution of Additional Phosphorus Demand in Subtropical China}

We define the zones in the north of $30^{\circ} \mathrm{N}$, between $25^{\circ} \mathrm{N}$ and $30^{\circ} \mathrm{N}$, and in the south of $25^{\circ} \mathrm{N}$ in the study area as northern, central and southern subtropical China, respectively. The NPP trends averaged over northern, central and southern subtropical China for EBF are $1.63 \mathrm{gC} \cdot \mathrm{m}^{-2} \cdot \mathrm{a}^{-1}, 2.02 \mathrm{gC} \cdot \mathrm{m}^{-2} \cdot \mathrm{a}^{-1}$ and $1.79 \mathrm{gC} \cdot \mathrm{m}^{-2} \cdot \mathrm{a}^{-1}$, respectively, and those for ENF are $1.23 \mathrm{gC} \cdot \mathrm{m}^{-2} \cdot \mathrm{a}^{-1}, 1.38 \mathrm{gC} \cdot \mathrm{m}^{-2} \cdot \mathrm{a}^{-1}$ and $1.27 \mathrm{gC} \cdot \mathrm{m}^{-2} \cdot \mathrm{a}^{-1}$, respectively. For both EBF and ENF, the highest NPP trends occurred in central subtropical China, and the lowest in northern subtropical China, and the NPP trend for EBF was higher than that for ENF in the whole subtropical China. 
The AAPD trends over 1951-2010 for EBF in northern, central and southern subtropical China are $3.44 \mathrm{mg} \cdot \mathrm{m}^{-2} \cdot \mathrm{a}^{-1}, 4.25 \mathrm{mg} \cdot \mathrm{m}^{-2} \cdot \mathrm{a}^{-1}$ and $3.91 \mathrm{mg} \cdot \mathrm{m}^{-2} \cdot \mathrm{a}^{-1}$, respectively, and those for ENF are $2.00 \mathrm{mg} \cdot \mathrm{m}^{-2} \cdot \mathrm{a}^{-1}, 2.14 \mathrm{mg} \cdot \mathrm{m}^{-2} \cdot \mathrm{a}^{-1}$ and $1.91 \mathrm{mg} \cdot \mathrm{m}^{-2} \cdot \mathrm{a}^{-1}$, respectively. The latitudinal distribution of AAPD trends is consistent with that of NPP trends. For both EBF and ENF, the highest AAPD trend occurs in central subtropical China, and the lowest in northern subtropical China. While the AAPD trends for EBF are higher than those for ENF in the whole subtropical China. Therefore, the central subtropical forests, especially the EBF, have the highest increasing trends of NPP and P demands over 1951-2010 due to climate warming.

\subsection{Observed Soil Available Phosphorus in Forest Sites}

Based on the field investigations conducted in the summer of 2018, the observed ASP in Shennongjia, Qian Yanzhou, Mt.Gongga and Dinghushan are $1.24 \mathrm{mg} \cdot \mathrm{kg}^{-1}, 1.43 \mathrm{mg} \cdot \mathrm{kg}^{-1}, 5.24 \mathrm{mg} \cdot \mathrm{kg}^{-1}$ and $3.15 \mathrm{mg} \cdot \mathrm{kg}^{-1}$ for EBF, and $1.63 \mathrm{mg} \cdot \mathrm{kg}^{-1}, 1.45 \mathrm{mg} \cdot \mathrm{kg}^{-1}, 1.98 \mathrm{mg} \cdot \mathrm{kg}^{-1}$ and $1.53 \mathrm{mg} \cdot \mathrm{kg}^{-1}$ for ENF, respectively. The spatial variations of ASP range from $1.24 \mathrm{mg} \cdot \mathrm{kg}^{-1}$ to $5.24 \mathrm{mg} \cdot \mathrm{kg}^{-1}$ among forest sites for EBF, which are greater than that for ENF. The latter range from $1.45 \mathrm{mg} \cdot \mathrm{kg}^{-1}$ to $1.98 \mathrm{mg} \cdot \mathrm{kg}^{-1}$ among forest sites. Based on the soil bulk densities observed in corresponding plots, ASP could be changed to ASP density (Table 2). The ASP densities in Shennongjia, Qian Yanzhou, Mt.Gongga and Dinghushan are $812 \mathrm{mg} \cdot \mathrm{m}^{-2}, 937 \mathrm{mg} \cdot \mathrm{m}^{-2}, 3432 \mathrm{mg} \cdot \mathrm{m}^{-2}$ and $2063 \mathrm{mg} \cdot \mathrm{m}^{-2}$ for EBF and $1068 \mathrm{mg} \cdot \mathrm{m}^{-2}, 950 \mathrm{mg} \cdot \mathrm{m}^{-2}$, $1297 \mathrm{mg} \cdot \mathrm{m}^{-2}$ and $1001 \mathrm{mg} \cdot \mathrm{m}^{-2}$ for ENF, respectively. The variations of ASP density among forest sites for EBF are also larger than those for ENF. In addition, the differences in soil bulk densities in each forest plot also contribute to the ASP density differences among forest sites and forest types.

Table 2. Observed available soil phosphorus (ASP) $\left(\mathrm{mg} \cdot \mathrm{m}^{-2}\right)$ in 2018 and the accumulated additional phosphorus demand (AAPD) $\left(\mathrm{mg} \cdot \mathrm{m}^{-2}\right)$ for the period of 1951-2010 for $\mathrm{S}_{1}$ and $\mathrm{S}_{2}$.

\begin{tabular}{ccccccc}
\hline \multirow{2}{*}{ Forest Site } & \multicolumn{2}{c}{ ASP } & \multicolumn{2}{c}{ AAPD (AAPD/ASP) for $\mathbf{S}_{1}$} & \multicolumn{2}{c}{ AAPD (AAPD/ASP) for $\mathbf{S}_{2}$} \\
\cline { 2 - 6 } & EBF & ENF & EBF & ENF & EBF & ENF \\
\hline Shennongjia & 812 & 1068 & $173(21.4)$ & $99(9.3)$ & $17(2.1)$ & $10(0.9)$ \\
\hline Qian Yanzhou & 937 & 950 & $239(25.5)$ & $120(12.7)$ & $24(2.6)$ & $12(1.3)$ \\
\hline Mt. Gongga & 3432 & 1297 & $231(6.7)$ & $113(0.87)$ & $23(0.7)$ & $11(0.1)$ \\
\hline Dinghushan & 2063 & 1001 & $180(8.7)$ & $86(0.86)$ & $18(0.9)$ & $9(0.1)$ \\
\hline
\end{tabular}

The numbers in the brackets are the values of AAPD/ASP (\%). EBF and ENF are the abbreviations for evergreen broad leaf forest and evergreen needle leaf forest, respectively. $S_{1}$ and $S_{2}$ are the scenarios for the low and high mineralization rates, respectively.

\subsection{Past Phosphorus Consumptions in Forest Sites}

To estimate the past $\mathrm{P}$ consumptions in the four representative forest sites, we calculated the AAPD for the period of 1951-2010 and their proportions to ASP and AAPD/ASP (Table 2). The AAPD are greater in EBF than in ENF in all sites. For $\mathrm{S}_{1}$, the AAPD and AAPD/ASP in Qian Yanzhou are $239 \mathrm{mg} \cdot \mathrm{m}^{-2}$ and $25.5 \%$ for EBF, and $120 \mathrm{mg} \cdot \mathrm{m}^{-2}$ and $12.7 \%$ for ENF, which are the highest among the forest sites. Followed by Shennongjia, with an AAPD and AAPD/ASP of $173 \mathrm{mg} \cdot \mathrm{m}^{-2}$ and $21.4 \%$ for EBF, and $99 \mathrm{mg} \cdot \mathrm{m}^{-2}$ and $9.3 \%$ for ENF. The AAPD/ASP in Mt. Gongga and Dinghushan are relatively smaller than that in Qian Yanzhou and Shennongjia. The AAPD and AAPD/ASP for $\mathrm{S}_{1}$ are nine to ten times those for $\mathrm{S}_{2}$.

\subsection{Prediction of Future Phosphorus Limitation in Forest Sites}

To reveal if the past increasing trend in additional $P$ demand will continue in subtropical China, we used the outputs of BCC-CSM 1.1 to estimate the future AAPD in the four forest sites. The temperature will be increased by $4{ }^{\circ} \mathrm{C}, 3.4^{\circ} \mathrm{C}, 2.9^{\circ} \mathrm{C}$ and $2.3^{\circ} \mathrm{C}$, while the NPP will be increased by $327 \mathrm{gC} \cdot \mathrm{m}^{-2} \cdot \mathrm{a}^{-1}$, $368 \mathrm{gC} \cdot \mathrm{m}^{-2} \cdot \mathrm{a}^{-1}, 371 \mathrm{gC} \cdot \mathrm{m}^{-2} \cdot \mathrm{a}^{-1}$ and $381 \mathrm{gC} \cdot \mathrm{m}^{-2} \cdot \mathrm{a}^{-1}$ in Shennongjia, Qian Yanzhou, Mt. Gongga and 
Dinghushan, respectively, by 2099 under RCP8.5, compared with that in 2018 (Table 3). Future climate warming will stimulate the increase of NPP at an average rate of $4.2 \mathrm{gC} \cdot \mathrm{m}^{-2} \cdot \mathrm{a}^{-2}$ in the four sites, which are more than double that during 1951-2010. For the four sites, future AAPD are estimated in the range of $568-668 \mathrm{mg} \cdot \mathrm{m}^{-2}$ and $57-67 \mathrm{mg} \cdot \mathrm{m}^{-2}$.

Table 3. Predicted temperature and NPP difference as well as P limitation in forest sites in subtropical China under RCP8.5.

\begin{tabular}{ccccc}
\hline \multirow{2}{*}{ Forest Site } & $\boldsymbol{\Delta} \mathbf{T}\left({ }^{\circ} \mathbf{C}\right)$ & $\mathbf{\Delta N P P}\left(\mathbf{g C} \cdot \mathbf{m}^{-2} \cdot \mathbf{a}^{-1}\right)$ & \multicolumn{2}{c}{ AAPD $\left(\mathbf{m g} \cdot \mathbf{m}^{-2}\right)$} \\
\cline { 4 - 5 } & & 327 & $\mathbf{S}_{1}$ & $\mathbf{S}_{2}$ \\
\hline Shennongjia & 3.99 & 368 & 568 & 57 \\
Qian Yanzhou & 3.41 & 371 & 644 & 65 \\
Mt. Gongga & 2.91 & 381 & 651 & 65 \\
Dinghushan & 2.32 & 668 & 67 \\
\hline
\end{tabular}

$\Delta \mathrm{T}$ and $\triangle \mathrm{NPP}$ represent temperature and NPP difference between 2099 and 2018. The accumulated additional phosphorus demand (AAPD) is for the period of 2018-2099, and ASP is the available soil phosphorus observed in 2018. $S_{1}$ and $S_{2}$ are the scenarios for the low and high mineralization rates, respectively.

The AAPD/ASP indicates the proportions of $\mathrm{P}$ consumption to $\mathrm{P}$ supply. The higher the values, the higher the degree of potential P limitation. By the end of the 21st century, for RCP8.5, the AAPD/ASP values for the four forest sites are predicted to be in the range of $32.2 \%$ to $68.4 \%$ under $\mathrm{S}_{1}$, and in the range of $3.3 \%$ to $6.3 \%$ under $\mathrm{S}_{2}$. For RCP4.5, the AAPD/ASP values for the four forest sites are predicted in the range of $12.8 \%$ to $32.1 \%$ under $\mathrm{S}_{1}$, and in the range of $1.3 \%$ to $3.2 \%$ under $\mathrm{S}_{2}$ (Table 4 ).

Compared with the predicted AAPD/ASP in RCP4.5, the predicted AAPD/ASP in RCP8.5 is greater in each forest site. For both $\mathrm{S}_{1}$ and $\mathrm{S}_{2}$, from RCP8.5 to RCP4.5, the AAPD/ASP decreased by about $48.3 \%$, $63.8 \%, 60.2 \%$ and $42.6 \%$ in Shennongjia, Qian Yanzhou, Mt. Gongga and Dinghushan, respectively.

Table 4. Comparison of AADP/ASP (\%) for RCP8.5 and RCP4.5 among forest sites for the low and high mineralization rate scenarios.

\begin{tabular}{ccccc}
\hline Scenario & Shennongjia & Qian Yanzhou & Mt. Gongga & Dinghushan \\
\hline RCP4.5 $\left(\mathrm{S}_{1}\right)$ & 32.1 & 24.7 & 12.8 & 27 \\
RCP8.5 $\left(\mathrm{S}_{1}\right)$ & 62.2 & 68.4 & 32.2 & 47 \\
RCP4.5 $\left(\mathrm{S}_{2}\right)$ & 3.2 & 2.5 & 1.3 & 2.7 \\
RCP8.5 $\left(\mathrm{S}_{2}\right)$ & 6.3 & 6.9 & 3.3 & 4.7 \\
\hline
\end{tabular}

$S_{1}$ and $S_{2}$ are the scenarios for the low and high mineralization rates, respectively. The accumulated additional phosphorus demand (AAPD) is for the period of 2018-2099, and ASP is the available soil phosphorus observed in 2018.

\section{Discussion}

In this study, we analyzed the spatial and temporal variations of model-simulated NPP during 1951-2010 in subtropical China. Based on the variations of NPP, we estimated the AAPD over 1951-2010. We predicted future P limitation based on field observations of current ASP and model simulated future NPP. Our results demonstrated that climate warming has caused the increase of NPP and P demands in subtropical forests in China, and future climate change will likely continue to increase NPP and enhance P limitations in subtropical China.

\subsection{Factors Affecting Phosphorus Limitation in Subtropical China}

Though the additional $\mathrm{P}$ demand over 1951-2010 varied among forest sites and forest types, the $\mathrm{P}$ limitations are largely dependent on current ASP. For example, the AAPD for EBF in Mt. Gongga is higher $\left(231 \mathrm{mg} \cdot \mathrm{m}^{-2}\right)$, but the AAPD/ASP there is the lowest $(6.7 \%)$ among the EBFs in the four sites (Table 2), which indicates the importance of the ASP in determining the intensity of P limitation, and hence, it is necessary to investigate the spatial distribution of ASP in subtropical China. 
Our estimates of ASP density show a large variety among sites and forest types. The ASP density is controlled by many factors, such as the parent material, soil weathering regime, biota, and the relative importance of these controls during soil development [51]. Therefore, the large variety in observed ASP density is understandable. Cao et al. (2014) reported that the observed ASP densities in the central subtropical region $\left(109^{\circ} 45^{\prime} \mathrm{E}, 26^{\circ} 50^{\prime} \mathrm{N}\right)$ for ENF are in the range of $620-840 \mathrm{mg} \cdot \mathrm{m}^{-2}$ [55], which are lower than our estimate of the ASP density for ENF in Qian Yanzhou. Zhang et al. (2005) demonstrated that the average ASP in tropical and subtropical China is $4800 \mathrm{mg} \cdot \mathrm{m}^{-3}$ in the top $50 \mathrm{~cm}$ soil [51], which could be changed to a density of $2400 \mathrm{~g} \cdot \mathrm{m}^{-2}$ for comparison in this study, and is close to our estimates of ASP density in Mt. Gongga.

The AAPD/ASP for both EBF and ENF in Qian Yanzhou are the highest among those in the forest sites, and are due to higher AAPD and lower ASP. The forests in Qian Yanzhou are plantations, which implies human activities may have decreased the ASP there. According to the eighth national inventory of forest resources, there are 41.06 million hectares of plantations in subtropical China, which account for $19.8 \%$ of China's total forest area. Cao et al. (2014) reported an even lower (less than $840 \mathrm{mg} \cdot \mathrm{m}^{-2}$ ) ASP in plantations in the central subtropical region near Qian Yanzhou [55], which implies lower ASP may widely exist in the subtropical plantations.

\subsection{Comparison of Past and Future Phosphorus Limitations in Subtropical China}

By the end of this century, the model-predicted NPP in the four forest sites will continue to increase under RCP8.5. To compare the intensity of P limitation in 1951-2010 with that in 2018-2099, we calculated the AAPD/ $\Delta t$ in the two periods, where $\Delta t$ is the length of the time period. The AAPD/ $\Delta t$ averaged over the four sites for $S_{1}$ and $S_{2}$ are, respectively, $2.58 \mathrm{mg} \cdot \mathrm{m}^{-2} \cdot \mathrm{a}^{-1}$ and $0.26 \mathrm{mg} \cdot \mathrm{m}^{-2} \cdot \mathrm{a}^{-1}$ for $1951-2010$, and $7.62 \mathrm{mg} \cdot \mathrm{m}^{-2} \cdot \mathrm{a}^{-1}$ and $0.77 \mathrm{mg} \cdot \mathrm{m}^{-2} \cdot \mathrm{a}^{-1}$ for 2018-2099. The AAPD/ $\Delta t$ for 2018-2099 is about 2.95 times more than that for 1951-2010, which indicates P limitations will be greatly enhanced in subtropical forests in China under RCP8.5.

The intensity of P limitation in Qian Yanzhou is the highest among the forest sites for the period of 1951-2010, and the future AAPD/ $\Delta \mathrm{t}$ in Qian Yanzhou is also the highest, which implies the plantations in central subtropical China are likely to face the highest risks of $P$ limitation in the future.

\subsection{Comparison of Phosphorus Limitations between Low and High Mineralization Rate Scenarios}

Mineralization processing is an important source of $\mathrm{P}$ supply. The mechanism affecting the mineralization process of organic $P$ is complex. In this paper, the $S_{1}$ scenario assumes that only the litters of leaf could be mineralized, and the $S_{2}$ scenario assumes that all litters, including root, stem and leaf, could be mineralized. The estimated AAPD over 1951-2010 for $S_{1}$ and $S_{2}$ are quite different. Take ENF as an example, the AAPD averaged over ENF were estimated as $160 \mathrm{~m} g P \cdot \mathrm{m}^{-2}$ for $\mathrm{S}_{1}$, and $16 \mathrm{mgP} \cdot \mathrm{m}^{-2}$ for $\mathrm{S}_{2}$. From $\mathrm{S}_{1}$ to $\mathrm{S}_{2}$, the AAPD decreased by $90 \%$. Therefore, the intensity of the mineralization rate is extremely important for determining the degree of $\mathrm{P}$ limitation in subtropical China. The human-managed subtropical plantations, with wood harvest, may correspond to $S_{1}$, and the natural subtropical forests without human disturbance are more likely to correspond to $S_{2}$. The observed ASP in Qian Yanzhou plantations is the lowest among forest sites, which confirms that human activities may decrease forest ASP.

\subsection{Comparison of Phosphorus Limitation with Other Studies}

Previous studies on P limitation revealed that the major sources of uncertainty are related to the estimates of ASP, the stoichiometry of plant organs and the proportion of NPP allocation to plant organs [33]. In this study, we obtained biome-specific C:P ratios for leaves, wood and roots, and NPP allocation to $C$ pools (leaves, wood and roots) from literatures which reported field measurements in subtropical China. Furthermore, we conducted field observations in representative forest sites to estimate ASP, which could reduce the uncertainty of P limitation studies in subtropical China. 
If we define the P deficit at the end of this century as the difference between ASP in 2018 and the AAPD for the period of 2018-2099, then the P deficit will be 372, 300, 1714 and $865 \mathrm{mg} \cdot \mathrm{m}^{-2}$ for $\mathrm{S}_{1}$, and 883, 879, 2299 and $1465 \mathrm{mg} \cdot \mathrm{m}^{-2}$ for $\mathrm{S}_{2}$ for RCP8.5 in Shennongjia, Qian Yanzhou, Mt. Gongga and Dinghushan, respectively. Sun et al. (2017) estimated the P deficit in these areas were in the range of $-25,000 \mathrm{mg} \cdot \mathrm{m}^{-2}$ to $15,000 \mathrm{mg} \cdot \mathrm{m}^{-2}$ for $\mathrm{S}_{1}$, and $5000 \mathrm{mg} \cdot \mathrm{m}^{-2}$ to $25,000 \mathrm{mg} \cdot \mathrm{m}^{-2}$ for $\mathrm{S}_{2}$ [33]. Our study refines this estimation to the range between 300 and $1714 \mathrm{mg} \cdot \mathrm{m}^{-2}$ and 879 and $2299 \mathrm{mg} \cdot \mathrm{m}^{-2}$ for $S_{1}$ and $S_{2}$, respectively. In this study, we assumed 1950 as the year of steady status, which may lower our estimates of P deficit when compared with other studies which assumed 1860 as the year of steady status.

\subsection{Limitations and Further Studies}

While great efforts have been made to reduce the uncertainties in the diagnosing of the $\mathrm{P}$ limitations in subtropical China, there are still some sources of uncertainty that were not taken into account in this study. First, the synergistic effect of $\mathrm{N}$ and $\mathrm{P}$ is neglected, which may result in higher estimation of AAPD in N-limited areas. Second, ecosystem-level manipulation experiments have shown that climate warming will gradually change the C:P ratios in ecosystems $[1,56,57]$, while human activities, such as fertilization and pollution, also changes $C: P$ ratios in ecosystems $[1,56,57]$. However, the $C: P$ ratios for plant organs are assumed to be constant during the study periods. Third, the allocations of vegetation carbon to roots, stem and leaves are assumed to be constant, but are changed with nutrient availability [58].

Further studies are needed to better understand and quantify the effects of N-P interactions, dynamic C:P ratios and vegetation carbon allocations on the $\mathrm{P}$ limitation. A comprehensive sensitivity analysis would help us to improve our understanding of the uncertainties, and will be an important part of our future research. In addition, the distribution of current ASP in subtropical China has large heterogeneity [59], and is a major factor affecting the degrees of P limitation, and, hence, further studies need to conduct more field investigations to understand the spatial distribution of ASP and P limitation in subtropical China.

\section{Conclusions}

We diagnose $\mathrm{P}$ limitation in subtropical forests in China under climate warming based on model-simulated NPP. The forest NPP in subtropical China increased significantly in recent decades, and the P limitation has been strengthened due to climate warming. The AAPD in 1981-2010 are 1.67 and 1.8 times that in the former 30 years for EBF and ENF, respectively. The higher AAPD sporadically distributed in the western subtropical China for the period of 1951-1980, but covered large areas of central and eastern subtropical China for the period of 1981-2010.

The observed current ASP density in forest sites varied from 812 to $3432 \mathrm{mg} \cdot \mathrm{m}^{-2}$ in EBF and 950 to $1297 \mathrm{mg} \cdot \mathrm{m}^{-2}$ in ENF, and the AAPD/ASP for EBF were greater than those for ENF. The AAPD for $\mathrm{S}_{1}$ is about 10 times that for $\mathrm{S}_{2}$. The AAPD/ASP in the four sites varied between $6.7 \%$ and $25.5 \%$ for EBF, and between $0.86 \%$ and $12.7 \%$ for ENF for the period of 1951-2010 for $S_{1}$.

Future climate change will enhance $P$ limitation in the four sites. The increasing trends of forest NPP will be doubled, and the AAPD/ASP are estimated to be in the range of $32.2-68.3 \%$ and $3.2-6.9 \%$ for $S_{1}$ and $S_{2}$, respectively, under RCP8.5 at the end of this century.

Though climate warming is one of the major factors in increasing the intensity of $\mathrm{P}$ limitation in subtropical forest in China, human disturbance is also another important factor. The $\mathrm{S}_{1}$ corresponds to low recycling of $\mathrm{P}$ by plants, which is more likely to correspond to forests with human disturbance. Therefore, future $\mathrm{P}$ limitation in subtropical China forest to some degree depends on human activities, and intense human disturbance will strengthen P limitation. In addition, the amount of current ASP is another factor that affects the intensity of $P$ limitation in subtropical China, and understanding the current ASP distribution is essential for understanding the intensity of P limitation in subtropical China. 
Author Contributions: Conceptualization, F.G., H.Y. and S.W.; Data curation, Z.W., X.S., W.X., F.Y. and G.C.; Formal analysis, Z.W.; Investigation, X.S., W.X., F.Y. and G.C.; Methodology, M.H. and F.G.; Project administration, M.H., H.Y. and S.W.; Resources, M.H. and H.H.; Software, N.W.; Supervision, Z.W.; Validation, X.S., W.X., F.Y. and G.C.; Visualization, N.W.; Writing-original draft, N.W.; Writing-review \& editing, M.H.

Funding: This study is supported by the Chinese National Natural Science Fund (No. 41671101), the Strategic Priority Research Program (XDA20010202) for the Chinese Academy of Sciences, the National Key Research and Development Program of China (2017YFC0503905) and the State Key Laboratory of Loess and Quaternary Geology, Institute of Earth Environment, CAS (SKLLQG1835).

Conflicts of Interest: The authors declare no conflict of interest.

\section{References}

1. Sistla, S.A.; Schimel, J.P. Stoichiometric flexibility as a regulator of carbon and nutrient cycling in terrestrial ecosystems under change. New Phytol. 2012, 196, 68-78. [CrossRef] [PubMed]

2. De Graaff, M.; Van Groenigen, K.; Six, J.; Hungate, B.K. Interactions between plant growth and soil nutrient cycling under elevated $\mathrm{CO}_{2}$ : A meta-analysis. Glob. Chang. Biol. 2010, 12, 2077-2091. [CrossRef]

3. Elser, J.; Bracken, M.; Cleland, E.; Gruner, D.; Harpole, W.; Hillebrand, H.; Ngai, J.; Seabloom, E.; Shurin, J.; Smith, J. Global analysis of nitrogen and phosphorus limitation of primary producers in freshwater, marine and terrestrial ecosystems. Ecol. Lett. 2007, 10, 1135-1142. [CrossRef] [PubMed]

4. Chapin, F.S.I. The mineral nutrition of wild plants. Annu. Rev. Ecol. Syst. 1980, 11, 233-260. [CrossRef]

5. Aerts, R.; Chapin, F.S. The Mineral Nutrition of Wild Plants Revisited: A Re-evaluation of Processes and Patterns. Adv. Ecol. Res. 2000, 30, 1-67.

6. IPCC. Climate Change 2014: Synthesis Report; Cambridge University Press: Cambridge, UK, 2014.

7. Delpierre, N.; Soudani, K.; Francois, C.; Köstner, B.; Pontailler, J.Y.; Nikinmaa, E.; Misson, L.; Aubinet, M.; Bernhofer, C.; Granier, A.; et al. Exceptional Carbon Uptake in European Forests during the Warm Spring of 2007: A Data-Model Analysis. Glob. Chang. Biol. 2009, 15, 1455-1474. [CrossRef]

8. Wu, Z.; Dijkstra, P.; Koch, G.; Penuelas, J.; Hungate, B. Responses of Terrestrial Ecosystems to Temperature and Precipitation Change: A Meta-Analysis of Experimental Manipulation. Glob. Chang. Biol. 2011, 17, 927-942. [CrossRef]

9. Nemani, R.R.; White, M.A.; Pierce, L.; Votava, P.; Coughlan, J.; Running, S.W. Biospheric monitoring and ecological forecasting. Am. Geophys. Union 2003, 12, 6.

10. Friedlingstein, P.; Cox, P.; Betts, R.; Bopp, L.; von Bloh, W.; Brovkin, V.; Cadule, P.; Doney, S.; Eby, M.; Fung, I.; et al. Climate-Carbon Cycle Feedback Analysis: Results from the C4MIP Model Intercomparison. J. Clim. 2006, 19, 3337-3353. [CrossRef]

11. Ito, A. A historical meta-analysis of global terrestrial net primary productivity: Are estimates converging? Glob Chang Biol. Glob. Chang. Biol. 2011, 17, 3161-3175. [CrossRef]

12. Cao, M.; Prince, S.; Li, K.; Tao, B.; Small, J.; Shao, X. Response of Terrestrial Carbon Uptake to Climate Interannual Variability in China. Glob. Chang. Biol. 2003, 9, 536-546. [CrossRef]

13. Fang, J.; Piao, S.; Field, C.B.; Pan, Y.; Guo, Q.; Zhou, L.; Peng, C.; Tao, S. Increasing Net Primary Production in China from 1982 to 1999. Front. Ecol. Environ. 2003, 1, 293-297. [CrossRef]

14. Piao, S.; Fang, J.; Zhou, L.; Zhu, B.; Tan, K.; Tao, S. Changes in vegetation net primary productivity from 1982 to 1999 in China. Glob. Biogeochem. Cycles 2005, 19. [CrossRef]

15. Gu, F.; Zhang, Y.; Huang, M.; Tao, B.; Guo, R.; Yan, C. Effects of climate warming on net primary productivity in China during 1961-2010. Ecol. Evol. 2017, 7, 6736-6746. [CrossRef]

16. Ji, J.; Huang, M.; Li, K. Prediction of carbon exchanges between China terrestrial ecosystem and atmosphere in 21st century. Sci. China 2008, 51, 885-898. [CrossRef]

17. Walker, T.W.; Syers, J.K. The fate of phosphorus during pedogenesis. Geoderma 1976, 15, 1-19. [CrossRef]

18. Vitousek, P.M.; Howarth, R.W. Nitrogen limitation on land and in the sea: How can it occur? Biogeochemistry 1991, 13, 87-115. [CrossRef]

19. Vitousek, P.M. Litterfall, Nutrient Cycling, and Nutrient Limitation in Tropical Forests. Ecology 1984, 65, 285-298. [CrossRef]

20. Okin, G.; Mladenov, N.; Wang, L.; Cassel, D.; Caylor, K.K.; Ringrose, S.; Macko, S.A. Spatial patterns of soil nutrients in two southern African savannas. J. Geophys. Res. Biogeosci. 2008, 113, G02011. [CrossRef] 
21. Mahowald, N.; Jickells, T.D.; Baker, A.R.; Artaxo, P.; Benitez-Nelson, C.R.; Bergametti, G.; Bond, T.C.; Chen, Y.; Cohen, D.D.; Herut, B. Global Distribution of Atmospheric Phosphorus Sources, Concentrations and Deposition Rates, and Anthropogenic Impacts. Glob. Biogeochem. Cycles 2008, 22, 37-42. [CrossRef]

22. Wang, W.; Tang, X.; Huang, M. Forest Ecosystem Carbon Stocks in China-Dynamics and Mechanisms; Science China Press: Beijing, China, 2018.

23. Huang, W.; Zhou, G.; Liu, X.; Zhang, D.; Xu, Z.; Liu, S. Effects of elevated carbon dioxide and nitrogen addition on foliar stoichiometry of nitrogen and phosphorus of five tree species in subtropical model forest ecosystems. Environ. Pollut. 2012, 168, 113-120. [CrossRef]

24. Huang, W.; Zhou, G.; Liu, J.; Duan, H.; Liu, X.; Fang, X.; Zhang, D. Shifts in soil phosphorus fractions under elevated $\mathrm{CO}_{2}$ and $\mathrm{N}$ addition in model forest ecosystems in subtropical China. Plant Ecol. 2014, 215, 1373-1384. [CrossRef]

25. Dong, W.Y.; Zhang, X.Y.; Liu, X.Y.; Fu, X.L.; Chen, F.S.; Wang, H.M.; Sun, X.M.; Wen, X.F. Responses of soil microbial communities and enzyme activities to nitrogen and phosphorus additions in Chinese fir plantations of subtropical China. Biogeosciences 2015, 12, 5537-5546. [CrossRef]

26. Kou, L.; Guo, D.; Yang, H.; Gao, W.; Li, S. Growth, Morphological Traits and Mycorrhizal Colonization of Fine Roots Respond Differently to Nitrogen Addition in a Slash Pine Plantation in Subtropical China. Plant Soil 2015, 391, 207-218. [CrossRef]

27. Zheng, M.; Huang, J.; Chen, H.; Wang, H.; Mo, J. Responses of Soil Acid Phosphatase and Beta-Glucosidase to Nitrogen and Phosphorus Addition in Two Subtropical Forests in Southern China. Eur. J. Soil Biol. 2015, 68, 77-84. [CrossRef]

28. Wang, Y.P.; Law, R.M.; Pak, B. A global model of carbon, nitrogen and phosphorus cycles for the terrestrial biosphere. Biogeosciences 2010, 7, 2261-2282. [CrossRef]

29. Goll, D.S.; Brovkin, V.; Parida, B.; Reick, C.H.; Kattge, J.; Reich, P.B.; Van Bodegom, P.; Niinemets, Ü. Nutrient limitation reduces land carbon uptake in simulations with a model of combined carbon, nitrogen and phosphorus cycling. Biogeosciences 2012, 9, 3547-3569. [CrossRef]

30. Yang, X.; Thornton, P.E.; Ricciuto, D.M.; Post, W.M. The role of phosphorus dynamics in tropical forests-A modeling study using CLM-CNP. Biogeosciences 2013, 11, 14439-14473. [CrossRef]

31. Peñuelas, J.; Poulter, B.; Sardans, J.; Ciais, P.; Van, d.V.M.; Bopp, L.; Boucher, O.; Godderis, Y.; Hinsinger, P.; Llusia, J. Human-induced nitrogen-phosphorus imbalances alter natural and managed ecosystems across the globe. Nat. Commun. 2013, 4, 2934. [CrossRef]

32. Wieder, W.R.; Cleveland, C.C.; Smith, W.K.; Todd-Brown, K. Future productivity and carbon storage limited by terrestrial nutrient availability. Nat. Geosci. 2015, 8, 441. [CrossRef]

33. Sun, Y.; Peng, S.; Goll, D.S.; Ciais, P.; Guenet, B.; Guimberteau, M.; Hinsinger, P.; Janssens, I.A.; Penuelas, J.; Piao, S.; et al. Diagnosing phosphorus limitations in natural terrestrial ecosystems in carbon cycle models. Earths Future 2017, 5, 730-749. [CrossRef]

34. Sheffield, J.; Goteti, G.; Wood, E.F. Development of a 50-Year High-Resolution Global Dataset of Meteorological Forcings for Land Surface Modeling. J. Climate 2006, 19, 3088-3111. [CrossRef]

35. Zhang, S.; Ping, G.; Huang, M. The Feature Extraction and Data Fusion of Regional Soil Textures Based on GIS Techniques. Clim. Environ. Res. 2004, 9, 65-79.

36. Ji, J. A Climate-Vegetation Interaction Model: Simulating Physical and Biological Processes at the Surface. J. Biogeogr. 1995, 22, 445. [CrossRef]

37. Huang, M.; Ji, J.; Li, K.; Liu, Y.; Yang, F.; Tao, B. The Ecosystem Carbon Accumulation after Conversion of Grasslands to Pine Plantations in Subtropical Red Soil of South China. Chem. Phys. Meteorol. 2007, 59, 439-448.

38. Wu, S.H.; Yin, Y.H.; Zhao, D.S.; Huang, M.; Shao, X.M.; Dai, E. Impact of future climate change on terrestrial ecosystems in China. Int. J. Climatol. 2010, 30, 866-873. [CrossRef]

39. Liu, W.; Su, J.; Li, S.; Zhang, Z.; Li, Z. Stoichiometry study of C, N and P in plant and soil at different successional stages of monsoon evergreen broadleaved forest in Pu'er, Yunnan Province. Acta Ecol. Sin. 2010, $30,6581-6590$.

40. Lin, X.; Wen, X.; Huang, F.; Gan, X.; Zhang, W.; Huang, Y. Ecological Stoichiometry Characteristics of Seedlings of Six Tropical and Subtropical Broad-leaved Tree Species. For. Environ. Sci. 2016, 32, 10-16.

41. Reed, S.C.; Townsend, A.R.; Davidson, E.A.; Cleveland, C.C. Stoichiometric patterns in foliar nutrient resorption across multiple scales. New Phytol 2012, 196, 173-180. [CrossRef] 
42. Zeng, Y.; Fang, X.; Xiang, W.; Deng, X.; Peng, C. Stoichiometric and Nutrient Resorption Characteristics of Dominant Tree Species in Subtropical Chinese Forests. Ecol. Evol. 2017, 7, 1-11. [CrossRef]

43. Fan, H.; Wu, J.; Liu, W.; Yuan, Y.; Hu, L.; Cai, Q. Linkages of Plant and Soil C:N:P Stoichiometry and Their Relationships to Forest Growth in Subtropical Plantations. Plant Soil 2015, 392, 127-138. [CrossRef]

44. Wright, I.J.; Reich, P.; Westoby, M.; Ackerly, D.; Baruch, Z.; Bongers, F.; Cavender-Bares, J.; Chapin, T.; Cornelissen, J.; Diemer, M.; et al. The World-Wide Leaf Economics Spectrum. Nature 2004, 428, 821-827. [CrossRef]

45. Wang, J.; Wang, S.; Li, R.; Yan, J.; Sha, L.; Han, S. C:N:P stoichiometric characteristics of four forest types'dominant tree species in China. Chin. J. Plant Ecol. 2011, 35, 587-595.

46. Li, L. C, N and P Ecological Stoichiometric Ratios among Leaves-Litter-Soil Systems in Secondary Forest of Different Degraded Stage in Middle Subtropics. Master's Thesis, Central South University of Forestry and Technology, Changsha, China, 2017.

47. Akritas, M.G.; Murphy, S.A.; Lavalley, M.P. The Theil-Sen Estimator With Doubly Censored Data and Applications to Astronomy. Publ. Am. Stat. Assoc. 1995, 90, 170-177. [CrossRef]

48. Fernandes, R.; Leblanc, S.G. Parametric (modified least squares) and non-parametric (Theil-Sen) linear regressions for predicting biophysical parameters in the presence of measurement errors. Remote Sens. Environ. 2005, 95, 303-316. [CrossRef]

49. Mann, H.B. Non-parametric tests against trend. Econ. J. Econ. Soc. 1945, 13, 163-171.

50. Kendall, M.G. Rank Correlation Methods; Griffin: London, UK, 1975.

51. Zhang, C.; Tian, H.; Liu, J.; Wang, S.; Liu, M.; Pan, S.; Shi, X. Pools and Distributions of Soil Phosphorous in China. Global Biogeochem. Cy. 2005, 19, GB1020. [CrossRef]

52. Tang, X.; Wang, Y.P.; Zhou, G.; Liu, S.; Liu, S.; Zhang, Q.; Liu, J.; Yan, J. Different patterns of ecosystem carbon accumulation between a young and an old-growth subtropical forest in Southern China. Plant Ecol. 2011, 212, 1385-1395. [CrossRef]

53. Olsen, S.R.; Sommers, L.E. Methods of Soil Analysis. Part 2. Chemical and Microbiological Properties; American Society of Agronomy, Soil Science Society of America: Madison, WI, USA, 1982.

54. Piao, S.; Ciais, P.; Lomas, M.; Beer, C.; Liu, H.; Fang, J.; Friedlingstein, P.; Huang, Y.; Muraoka, H.; Son, Y.; et al. Contribution of Climate Change and Rising $\mathrm{CO}_{2}$ to Terrestrial Carbon Balance in East Asia: A Multi-Model Analysis. Global Planet. Change 2011, 75, 133-142. [CrossRef]

55. Cao, J.; Yan, W.; Xiang, W.; Chen, X.; Lei, P.; Xiang, J. Characteristics of soil phosphorus in different aged stands of Chinese fir plantations in Huitong, Hunan Province. Acta Ecol. Sin. 2014, 34, 6519-6527.

56. Elser, J.J.; Fagan, W.F.; Kerkhoff, A.J.; Swenson, N.G.; Enquist, B.J. Biological stoichiometry of plant production: Metabolism, scaling and ecological response to global change. New Phytol. 2010, 186, 593-608. [CrossRef]

57. Yuan, Z.Y.; Chen, H.Y.H. Decoupling of nitrogen and phosphorus in terrestrial plants associated with global changes. Nat. Clim. Chang. 2015, 5, 465-469. [CrossRef]

58. Hermans, C.; Hammond JPWhite, P.J.; Verbruggen, N. How do plants respond to nutrient shortage by biomass allocation? Trends Plant Sci. 2006, 11, 610-617. [CrossRef]

59. Pizzeghello, D. Phosphorus cycle in agricultural soils. Phosphorus forms and P-sorption properties after long-term mineral and manure applications. Agric. Ecosyst. Environ. 2011, 141, 58-66. [CrossRef]

(C) 2019 by the authors. Licensee MDPI, Basel, Switzerland. This article is an open access article distributed under the terms and conditions of the Creative Commons Attribution (CC BY) license (http://creativecommons.org/licenses/by/4.0/). 